\title{
The Spiritual Utopia Reflected in Out of Africa
}

\author{
LIU Xi, WU Yi \\ Changchun University, Changchun, China
}

\begin{abstract}
The publication of Out of Africa in 1937 won Baroness K. Blixen-Finecke worldwide fame because the novel caused wide public concern among both critics and readers. The story unfolds a poetic picture which reveals the natural peace and harmony in Africa through the narrative angle of the heroine-Karen Blixen. In Out of Africa, the author, from multipoint viepoints, knits the legendary plot to display a picture of a community with the features of spiritual utopia, which is an ideal place for men to escape from the outside disturbance. The present paper, first, gives a brief introduction to the plot of the story. Then, it discusses the characteristics of spiritual utopian community on the African land from the following three perspectives: Karen Blixen is a pursuer to go after self-integrity so as to protect the harmony of spiritual utopian land in Africa; Africans are the paragons of self-integrity to pursue freedom on their homeland; and the western settlers are the dominators who have lost self-integrity in the spiritual utopian community because they have almost destroyed the ecological and social banlance on African land.
\end{abstract}

Keywords: spiritual utopia, equality, freedom, pursuer

\section{Introduction}

Out of Africa depicts a story which happened within 17 years after Blixen settled down in Kenya, British East Africa. The story began in 1913 when Blixen was 28 years old. She went to British East Africa to marry her cousin, the Swedish Baron Bror von Blixen-Finecke. Then the couple established their new family in Kenya, the British colony. Soon they bought a large piece of farmland in the Ngong Hills and then developed the farm into a coffee plantation. Thanks to the fortune in the business, the couple expanded their personal holdings as much as six thousand acres in 1917. However, in 1921 they broke up and soon they divorced. Karen took over the management of the farm by herself. Greatly independent and capable, she adapted herself to both cultivation and management of the farmland greatly. However, unfortunately, the farm deeply got involved in debts, thus, she had to sell it in 1931.

From a perspective of spiritual ecology, Blixen thoroughly focuses on man and herself, which supports the viewpoint that the integral selfhood plays a pivotal role in keeping a harmonious co-existence between man and nature, man and man. The meaningless and emptiness of human inner world and the crisis of faith-death of god-intensify people's desires and greed of domination. Regardless of evils that settlers have done to undermine the ecosystem, Blixen presents an ideal Africa for modern people, leading people to ponder on to pursue a poetic

LIU Xi, Master, Lecturer, School of Foreign Languages, Changchun University.

WU Yi, Master, Associate Professor, School of Foreign Languages, Changchun University. 
and peaceful living on earth. However, the white settlers, with material desires have the divided selfhood and doubt the existence of God. They merely trusted human's domination over the earth with human-centered theory.

This paper aims to discuss the features of the spiritual utopia constructed in Out of Africa from three perspectives: Karen Blixen can be viewed as the pursuer of self-integrity who seeks spiritual equality between whites and blacks; native Africans can be viewed as the paragons of spiritual utopia; and the white settlers acted as the losers to devastate the harmony and peace in the utopian land.

\section{The Pursuer of Self-integrity-Blixen}

In Out of Africa, Blixen came from Europe and lived a modern life there and went through the conversion from human-centered theory to ecological holism in Africa. It can be viewed as a soul journey to seek for an integral selfhood by integration with African highlands, local people and traditions as well as wild animals, simplifying lifestyle and making Africa her spiritual home.

Contrasted with those so-called white settlers, Blixen had changed a lot since she became a farmer in Africa. She had abandoned her hobby of hunting and put away her rifles. She had little pity for all her behaviors in her life except for cutting down trees round the house during the hard years. The fresh green and luxuriant branches of the forest haunted her and there was nothing more important than planting trees. The content and satisfaction in her inner heart lasted many years. Blixen was completely conquered by the natural beauty and the universal harmony in Africa. Living there brought Blixen the echo from nature and the inner call at the bottom of her heart.

Different from those white settlers, Blixen braced African traditions and established an intimate relationship with local people. She would like to give tobacco to old native mothers, present sugar to children, and enjoy life around the fire under the big clear moon. Blixen had quite different feelings to relating to the natives and the whites. With the natives, she showed respect and love to them, but when getting along with the white people, she felt the suffocation and the pedantry because of their hypocrisy, selfishness, and disharmony with nature.

The Africans' simple lifestyle was what Henry David Thoreau wrote about in Walden: “An honest man has hardly needed to count more than his ten fingers, or in extreme cases, he may add his ten toes, and lump the rest. Simplicity, simplicity, simplicity” (Thoreau, 2004, p. 91). It had a great influence upon Blixen by making her much simpler, truer, and more natural in Africa. Before of Blixen's departure, she gave away all her possessions and felt fearless before destiny for there is nothing to be worried about in life. Blixen treated local land as her spiritual home and there she perfected herself as an integral individual. In Africa, Blixen formed an intimate mutual reliance on African highlands and wild animals so as to establish a deep friendship with the natives.

There were calls from Africa to beckon Blixen. While most people toiled to earn a living, securing the future, Blixen devoted much attention and efforts to secure her past. Indeed, in the eyes of Blixen, Africa was not just the "past” but her own song of seeking self. It goes in this way "the fresh air over the plain quiver with a color that she has had on; the children create a game named after her; the full moon throws a shadow over the gravel of the drive that is like her; and the eagles of Ngong look out for her. Finally, Africa says to Blixen "I will not let thee go except thou bless me” (Blixen, 2000, p. 263). No matter how toughly people lived a life in Africa, there was always much vigor, a curious sweetness, a song, a youth, and a wild hope in their hearts. And it was during those long days that Africa and Blixen melted into a unity. She buried Africa deeply in her heart and finally finished the novel to praise the natives and presented her integral selfhood. 
"Natural utopia was a material concept while spiritual utopia was a psychological one” (Wells, 1997, p. 189). Nowadays, people know more about how to restrain environmental pollution, but they ignore how to restrain their swelling changing towards materialism and self-interest activism. In this sense, people can change the social situation and keep harmonious social relationship by beautifying our spirit, treasuring the beauty in people as well as environment. However, without social ecology, that is, "without a secure and reasonable society in which all things either living or non-living coexist harmoniously, inter-connectedly and interdependently, it is still a challenge to obtain natural and spiritual ecology” (Kumar, 1991, p. 77). Therefore, spiritual ecology is the core and natural ecology is the basis, however, social ecology is the guarantee of them two.

\section{The Paragon of Self-integrity-Africans}

When a man has the moral good, he will get an integral selfhood, and it is true of African natives in Out of Africa. The local people's close spiritual ties with nature, great reference for God and firm beliefs are all evidences to prove the natives' integral selfhood. In the eyes of Africans, nature was the creation of God and the representative coming to earth. Their intimacy with nature brought them the sense of divinity, richness, and happiness of the inner world. In their mind, they were blessed by nature and their integral selfhood kept them live with nature harmoniously.

In the novel, the telepathy between local people and nature was in their tradition, the big dances. It was said that Africans were born with musical talent. Because music was so important in the lives of many Africans and because so much music was performed in Africa, we were inclined to think that all Africans were musicians. The impression is strengthened when we look at ourselves and find that we have become largely a society of musical spectators. Music is important to us, but most of us can be considered consumers rather than producers of music. We have records, television, concerts, and radio to fulfill many of our musical needs. In most situations where music is performed in our culture it is not difficult to distinguish the audience from the performers, but such is often not the case in Africa.

Africans never doubted the existence of God so that they had firm faith in Him. In their eyes, God was ubiquitous. When Kamante, the little Cook, saw a big grass-fire at night, he came to Blixen’s room to tell her that "God is coming" and she should be ready to see Him. The natives always believed that God lived high above them. When Denys flied high in the sky and then landed on the plain, an elderly native asked him whether he saw the God, he replied that he was not sure if he was high enough to see God. The native was disappointed at his answer, wondering why Denys flied if he failed to see God. In the mind of local people, the earth, the moon, the wild animals, etc., were a proof of the existence of God, despite that there had been a faith crisis in Europe.

Africans were proud for themselves because they had firm beliefs, trusting in their own power with sympathy for any kind of machinery or mechanics. They had no concepts of luxury but only simplicity. In their cabins there was no such thing as a piece of furniture except a small wooden thing to sit on. The settlers had brought many things strange confronting their traditional beliefs. They faced all these changes with great calmness. They had no sense of risk, just living and enjoying in the present moment. In this respect, local people were like fishes swimming in deep water never fearing of drowning. They were accustomed to the unseen and the unexpected in friendly terms with destiny.

To native people, the destiny was their home with the same familiar darkness in their huts and deep mold for their roots. 
The local people are friends of nature and do not stand against God, never die in shackles. The country is his native land, and whatever you do him, when he goes he goes by his own free will, and because he does not want to stay. (Blixen, 2000, p. 271)

The natives viewed the nature as their protector and could always find a comfortable refuge shelter. The local people could hold their spiritual world freely to go whenever they wanted and no one could get hold of them. In conclusion, the Natives' close connection with divinity morality and integrity formed a spiritual utopia for modern people to admire and contemplate.

\section{The Losers of Self-identity-Western Settlers}

In an era of materialism and industrialism, modern people were filled with utilitarian thoughts. They were gradually away from the divine power, who believed in the death of God instead of existence. The modern people lost their faith, self-integrity, let alone the other regarding love, consequently, they got a divided selfhood and their disharmonious relation with other people and nature. Greed and desires had taken place of richness, depth, and meaning of life, leaving no room for aristocratic virtues, high purpose in life or things were worth dying for. What counted was egoistic material possession, which greatly intensified the conflict between human and nature and destroyed the harmonious connection between man and man, causing ecological crisis and cultural crisis.

The loss of the Westerners' faith just resembles that of the Lost Generation, a literature school original in American in the 20th century. Lost Generation refers to the generation after the World War I. Meanwhile, it refers to the young writers who lived as expatriates in Western Europe for a short time as well. Besides Hemingway, there are many other masters in the academic field, such as Lewis Mumford, Ezra Pound, T. S. Eliot, Matthew, Sherwood Anderson, and many other novelists. The Lost Generation is also called the Sad Young Man by F. Scott Fitzgerald in his book which describes the disillusioned younger generation after the First World War. The Lost Generation was a group of rebellious youth appeared in America after the First World War. The 1920s was an age of Prohibition. Alcoholic beverages were outlawed by a constitutional amendment. However, young people cheerfully evaded the law in thousands of "speakeasies" (illegal bars). They played jazz, took drugs, and bravely denunciated the Puritan morality and the social convention. At the same time, a lot of works appeared to reflect these young men's depression and sad emotion. They seemed to lose their directions for the future. To some extent, like the lost generation, modern people lose faith and when they are alone they feel empty and tired of the unpleasant world, with no shelter to escape.

The divided self of the white settlers was embodied in their separation from God since people come into the industrial age. They built many churches in Africa for evil purpose-assimilating the natives and gained more profits, never to spread the love of God. They made lots of rules as if they were the spokesmen of God to control Africans. The settlers firmly believed in their power to conquer and change everything since they acquired the advanced science and technology. They made local people believe that the highlands were the spread of God's ideas, however, the so-called God referred to the white settlers, which was a great irreverence to God. They were in general insecurity of existence in Africa for in pursuit of some shade and some darkness, they paid for it at the cost of abandoning the doctrine.

Life without faith is just like earth without sun. Without faith, we will lose the motivation of pursuit. Having faith, we will be the next miracle. Therefore, faith is the very thing that we cannot afford to lose. Albert Einstein 
said, "science without religion is lame, religion without science is blind" (Einstein, 1979, p. 26) With belief, science could count as valid. We can find belief takes up a great role in all walks of life. We all have our own belief. Some has belief in Buddhism; some has faith in Christianity; some has trust in Islam.

Without faith and selfhood, the white settlers were walking dead body without soul. Contrasted with the proud natives who found their happiness in the fulfillment of their duty to the community and their fulfillment of fate, the white settlers had lost the idea of God in making of them. Though they thought they greatly conquered and changed nature and man, they were infinitely small standing upon the endlessly big Africa. Worse still, when the settlers came back to Europe they also lost identities belonging to the modern society and felt like swinging between dream and reality. There was no denying that they completely lost their self-identity.

\section{Conclusion}

With the entrance of an era of industrialization and modernization, human's attitudes to nature have changed from exploitation to utilization greatly, which brought adverse effects upon the relation between man and man as well. People are in great fear of losing what they've already possessed and are driven by new forms of greed and lust. However, disharmony between nature and human society makes man go through endless mental sufferings. Moreover, the conflict between man and nature is intensified to the clash between whites and blacks, consequently, various collisions among different ethnic groups, nations, and genders. The ecological crisis has accelerated into cultural crisis confronting all the human races, which results in the racial and gender division of human world. Only if men make reflections upon themselves to reestablish a harmonious relation between nature and culture, can they finally acquire a well-balanced life in the industrialized world.

Out of Africa, is a novel full of hope and salvation. The equality and fraternity among Africans carry the symbolic significance of spiritual utopia which Blixen is in hot pursuit of. Both natural utopia and social utopia can be viewed as the basis of spiritual utopia. Influenced by peaceful inner world of native Africans, Blixen keeps on searching for her true self so as to establish an integral self. However, western settlers have lost their loyalty to God so that they dash into the sacred African land and finally destroy it willingly, which has brought the ecological crisis between man and nature. Blixen presents deep concern over man's future and warns people of the danger, hoping human can wake and strive to converse the worsening trend, to abandon the human-centered ideas and have the awareness of ecological ideology, which will lead to self-salvation.

\section{References}

Einstein, A. (1979). Autobiographical notes. Chicago: Open Court Publishing Company.

Ernst, B. (2000). The spirit of utopia. Redwood: Stanford University Press.

Thoreau, H. D. (2004). Walden. UK: CRW Publishing LTD.

Wells, H.G. (1997). A modern utopia. Lincoln: University of Nebraska Press.

Blixen, K. (2000). Out of Africa. Eastbourne: Gardners Books Ltd.

Kumar, K. (1991). Utopianism. Oxford: Blackwell Publishers Ltd..

Kumar, K. (1987). Utopia and anti-utopia in modern times. Oxford: Blackwell Publishers Ltd.

Lyman, T. (2003). Thinking utopia: Steps into other worlds. NY: Berghahn Books.

Rubinstein, A. T. (1988). American literature: Root and flower. Beijing: Foreign Languages Teaching and Research Press.

Wilfred L. G. (2004). A handbook of critical approaches to literature. Beijing: Foreign Language Teaching and Research Press. 